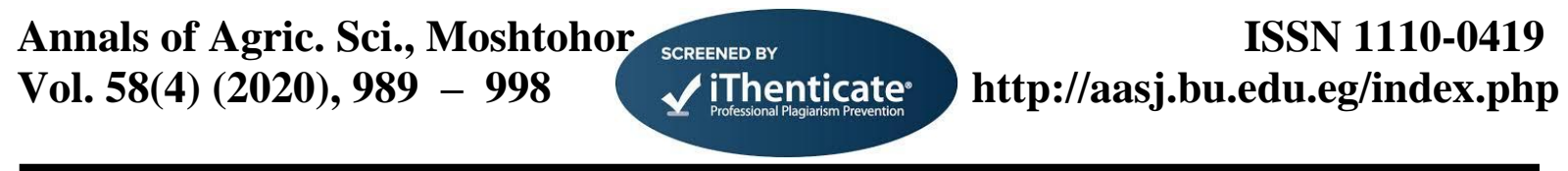

\title{
Response of Growth and Chemical Composition of Quercus robur,L.Seedlings to Organic and Inorganic Fertilizers.
}

\author{
Al-Atrash; E.E.N*., E. A.M. Osman** and A. I. El-Shafie** \\ *Forestry and timber Trees Dep. Hort. Res. Inst., Agric. Res. Centre, Giza, Egypt \\ **Soils, Water and Environ. Res. Inst., Agric. Res. Center (ARC), Giza, Egypt \\ Corresponding author: essamalatrash67@gmail.com
}

\begin{abstract}
This research aims to create a method for increasing the growth of Quercus robur, L seedlings, therfore pot experiment was conducted to study the response of growth and chemical composition for Quercus rubra seedlings to organic (potassium humate 5 or compost tea $15 \mathrm{~cm}^{3} /$ seedling) and inorganic fertilizers $50 \%$ (NPK at $15 \mathrm{~g} / \mathrm{seedling}$ ), $75 \%$ (NPK at 22.5g/seedling) and $100 \%$ (NPK at 30g/seedling)in the Experimental Farm of Horticultural Research Station of El-Kanater El-Khyria, Qaluobia Governorate, Egypt throughout two successive seasons of 2017/2018 and 2018/2019. The obtained results indicated that the significant values of increment height growth, stem diameter, root length ,biomass fresh and dry weight declared as a result to apply the treatment of 50\% NPK mineral plus compost tea 15 $\mathrm{cm}^{3}$ and K-humate $5 \mathrm{~cm}^{3} /$ seedlings followed by those of $75 \% \mathrm{NPK}+$ compost tea the intermediate values were exhibited with applying $75 \%$ NPK + compost tea or $75 \%$ NPK + K-humate and the latest in ranking was control, meaning that applying 50\% NPK plus compost tea and K-humate produced the superior seedlings more than the others. So it can be saved mineral nutrients by applying organic nutrients. Similar trend approximately revealed with total chlorophyll but total carbohydrates in stem pronounced the highest value with the treatment of compost tea alone. Concerning the content of N,P and K levels in plant it can be observed that a different values were occurred due to utilizing organic or inorganic nutrients and there is no clear trend and insignificant differences among the treatments. However N,P,K slightly increased with adding NPK at the different levels + compost tea or K-humate. It can be recommended from the above mentioned results that adding half dose of inorganic nutrients as 50\% NPK alongside compost tea and K-humate represented organic nutrients enhanced soil conditions led to producing healthy seedling of Quercus robur and reducing the doses of NPK as mineral nutrients.
\end{abstract}

Keywords: Quercus robur, L.mineral fertilizer, compost tea, , K-humate and pedunculate oak.

\section{Introduction}

The genus quercus comprises nearly 400 species that are distributed thought the temperate regions of the world (Johnson et al., 2002).English Oak. or pedunculate oak (Quercus robur) is an important forest species (family: Fagaceaae), deciduous with monoecious flowers. Outstanding can reach 40 meters height and 1 meter diameter, as they grow quite rapidly its wood is strong, tough, hard and durable, so it can be used for many purposes, specially ship building, furniture, veneer, parquets and sleepers. Besides, its wood is very good fuel and its bark is used for tanning (Manzanera et al., 1996). Oak is propagated by acorns sown immediately after collecting in fall good acorns harvests are irregular, and long term storage of acorns still presents unsolved problems, as they are considered "recalcitrant seeds" (Guthke and Spethmann, 1993). As well as, the long reproductive cycle of oak is a serious obstacle to effective tree improvement by conventional tree breeding techniques.

Many researchers have reported the nutritional requirements of macronutrients for some plants. In this concern, Abd-El-Aziz (2000) on Azadirachta indica, Attia et al., (2004)on Ficus benjamina, Shehata and Darwiesh, Mona (1999) on three Pinus species and Al-Atrashet al., (2015) on Khaya senegalensis and Cupressus sempervirens concluded that NPK fertilizers had an important physiological and biochemical functions on structure of photosynthetic pigments, metabolism of carbohydrates and protein. These effects were observed with significant increase in vegetative growth of the different plant species. Meanwhile, using of certain elements, nitrogen, phosphorus and potassium as major elements and Liberal as source of minor nutrients on Khaya senegalensis seedlings resulted in improving the vegetative growth, levels $\mathrm{N}, \mathrm{P}$ and $\mathrm{K}$ percentages and some wood properties as moisture content; specific gravity and fiber length as obtained by Sayed (2001). Excessive fertilization increases agricultural costs and can led to a variety of environmental issues while organic fertilizers have less impact upon the environment than chemical fertilizers, where most organic fertilizers contain relatively fewer nutrients but are released into the soil over an extended time. Furthermore, organic fertilizers also improve the soil structure by allowing better drainage, better retention of nutrients, and reducing the leached nitrate and mobility of phosphorus (Huang et al.,2012). A suitable combination of organic and inorganic source of nutrients is necessary for sustainable agriculture that can ensure food production with high quality (Ali $\boldsymbol{e t}$ al. 2009). 
Compost tea is a global impact for organic farming through recycling of organic waste for persistent agriculture as well as for a pollution-free environment. For the development of sustainable farming, waste enrichment is of interest. Involvement of earthworms (Eiseniafoetida) for the degradation of organic wastes and production of vermicompost is near commercialization (Kumar et al., 2001).Compost tea, in modern terminology, is a compost extract, plant extracts, liquid manures and it can be further understood in the context of their influences on the rhizosphere and phyllosphere. Also, manure and compost tea production is a brewing process that extracts microorganisms from compost or manure followed by microbial growth and multiplication including beneficial bacteria, fungi and protozoa (Ingham, 2005). Soil application of compost with compost tea gave better effect on all vegetative characteristics and leaves chemical constituents of macro and micro elements, total carbohydrates and $\mathrm{C} / \mathrm{N}$ ratio compared to control of pear trees (Mohammed $\boldsymbol{e t}$ al., 2010).Compost tea has been cited as an option for conventional and organic growers thought to enhance crop fertility by introducing microorganisms that might aid in improving soil characteristics(ElSharkawy (2007) on Guava and Osman et al., (2014) on Swietenia mahogany.

Humates absorb and breakdown minerals in the soil and hold them in an available state for utilization by the plant when required. Saruhanet al. (2011) stated that the humic compounds added to soil improved the soil fertility during raising the soil microbial population including beneficial microorganisms. They explained that humic substances are major components of organic matter, regularly constituting 60 to $70 \%$ of the total organic matter, thus they may increase the plant nutrients uptake during stimulation of microbiological activity. Humic substance increase soil organic matter, particularly for the sandy soil in Egypt and improves the physical, chemical and biological properties. Consequently, the availability of nutrients for plants as well as soil characteristics should be improved, Ulkan (2008) on Wheat and Osman et al., (2014) on Switenia mahogany.

The investigation aimed to improving growth of Quercus robur, L.seedlings affected by using different treatments of organic and inorganic fertilizers.

\section{Material and Methods}

This study was carried out at the Experimental Area of Horticulture Research Station at El-Kanater El-Khayria Qaluobia Governorate, Egypt throughout two successive seasons of 2017/2018 and 2018/2019. The main objective of this work is to investigate response of growth and chemical composition of Quercus robur,L. seedlings to organic and inorganic fertilizers.

\section{Physical and chemical properties of used soil:}

Soil has taken from ground surface layer at 0-30 depth then, physically and chemically properties were determined just before starting the experiment as shown in Table (1a) according to the methods described by Page et al., (1982) and Klute (1986). One-year-old uniform seedlings of Quercus robur were used, in average height of $15 \mathrm{~cm}$ and $0.8 \mathrm{~cm}$ diameter (at soil surface)and planted in black polyethylene bags $25 \mathrm{~cm}$ diameter and $35 \mathrm{~cm}$ length filled with about $8 \mathrm{~kg}$ of clay loam soil and irrigated up to field capacity.

Table .1 a. Physical and chemical analysis of used soil before starting the experiment in 2017/2018 season.

\begin{tabular}{|c|c|c|c|c|c|c|c|c|c|}
\hline \multirow{3}{*}{ Character } & \multicolumn{4}{|c|}{ (A) Physical analysis } & \multicolumn{5}{|c|}{ (B) Chemical analysis } \\
\hline & $\begin{array}{c}\text { Sand } \\
(\%)\end{array}$ & $\begin{array}{l}\text { Silt } \\
(\%)\end{array}$ & $\begin{array}{l}\text { Clay } \\
(\%)\end{array}$ & $\begin{array}{c}\text { Soil } \\
\text { texture }\end{array}$ & $\begin{array}{l}\text { E.C. } \\
\text { ds/m }\end{array}$ & $\begin{array}{c}\text { pH } \\
(1: 25)\end{array}$ & $\mathrm{CaCO}_{3}$ & $\begin{array}{c}\text { Organic } \\
\text { matter }(\%)\end{array}$ & $\begin{array}{c}\text { Available } \\
\text { (N) ppm }\end{array}$ \\
\hline & 19.6 & 41.44 & 38.96 & Clay loam & 1.28 & 7.79 & 2.76 & 1.08 & 38.4 \\
\hline \multirow{3}{*}{ Character } & \multicolumn{4}{|c|}{ Soluble cations meq/100 gmsoil } & \multicolumn{5}{|c|}{ Soluble Anions } \\
\hline & $\mathbf{C a}^{++}$ & $\mathbf{M g}^{++}$ & $\mathrm{Na}^{+}$ & $\mathbf{K}^{+}$ & $\mathrm{Cl}^{-}$ & $\mathrm{HCO}_{3}^{-}$ & $\mathrm{CO}_{3}^{-}$ & & $4^{--}$ \\
\hline & 3.32 & 1.87 & 5.33 & 0.9 & 3.98 & 4.15 & ـ & & 29 \\
\hline
\end{tabular}

The seedlings were planted on March, $5^{\text {th }} 2017$ and 2018 in both seasons, then distributed in completely randomized design included 7 treatments replicated three times and each replicate contained 21 seedlings. The seedlings were subjected in shade area and after one month from transplanting the seedlings were subjected outdoors to sunny area above sheets of thick polyethylene to prevent penetrate the growing roots into soil outer bags.

The treatments were as follows: 1- Control
2-Full mineral fertilization $(100 \%$ NPK at 30 g/seedling)

3 - Compost tea $(15 \mathrm{~cm} / \mathrm{seedling})$ as soil drench.

4- Potassium humate $(5 \mathrm{~cm} / \mathrm{seedling})$ as soil drench.

$5-75 \%$ (NPK at $22.5 \mathrm{~g} / \mathrm{seedling}$ ) + compost tea.

$6-75 \%$ ( NPK at $22.5 \mathrm{~g} /$ seedling $)+$ potassium humate.

7-50\%( NPK at $15 \mathrm{~g} / \mathrm{seedling})+$ compost tea + potassium humate.

Compound chemical fertilizer were added NPK $30 \mathrm{~g} / \mathrm{seedling}$ in the form of $(20 \% \mathrm{~N}: 20 \% \mathrm{P}: 20 \%$ $\mathrm{K}$ ), - Potassium humate (K-humate) $5 \mathrm{cmL}^{-1}$. Khumate was obtained from Soils, Water and 
Environment Research Institute, Agric. Research Center, Giza, Egypt. Compost Tea $15 \mathrm{~cm}^{3} /$ seedling was obtained by mixing a $1: 10(\mathrm{w}: \mathrm{v})$ ratio compost : distilled water)for 7 days at room temperature (Diver,2002,Scheuerell and Mahaffee 2002). Compost tea rough materials:

Different Agricultural wastes were used for preparing the experimented compost tea. The organic amendments included equal parts of the vegetative part of black night shade, the vegetative part of wormwood, stems of common reed and the vegetative part of white cattail Saber et al, (2011a and $\mathbf{b}$ ).

Composting:

To ensure uniformity, more surface area to microbial attack and rapid decomposition, the different plant materials were shredded to small pieces before being composted. The shredded plants were enriched with a chemical accelerator composed of $20-\mathrm{kg}$ ammonium sulphate, $10-\mathrm{kg}$ superphosphate, $50-\mathrm{kg}$ calcium carbonate and $100-\mathrm{kg}$ soil as microbial composting starter per ton dried plant material and wetted by both sheep's ruminant fluid at the rate of $10 \%$ of solid mass as complementary microbial composting starter and irrigating water at the rate of $50 \%$ of solid mass water holding capacity before being incubated at room temperature until maturity Saber et al., (2011a and b).

Aerated compost tea (ACT):

A plastic bucket was one third filled with one hundred and fifty gram portions quality finished compost of one of the seven organic amendments and wetted with water to its top. The slurry was thereafter steeped for 7 days before being stirred, aerated for 72 hours and strained through cheesecloth into another bucket, diluted 10 folds with water so it's the color of tea Saber et al., (2011 a).

K-humate and compost tea were applied as soil drench. The application of all treatments were divided into 4 doses at four times i.e., 2, 4, 6 and 8 months from transplanting.

Table 1-b. Chemical analysis of potassium humate and compost tea used in this study.

\begin{tabular}{|c|c|c|c|c|c|c|c|c|c|c|c|c|}
\hline & \multirow{2}{*}{ pH } & \multirow{2}{*}{$\begin{array}{c}\mathrm{EC} \\
(\mathrm{dS} / \mathrm{m})\end{array}$} & \multirow{2}{*}{$\begin{array}{l}\text { O.M } \\
(\%)\end{array}$} & \multirow{2}{*}{$\begin{array}{c}C \\
(\%)\end{array}$} & \multirow{2}{*}{$\begin{array}{l}\mathrm{C} / \mathrm{N} \\
\text { ratio }\end{array}$} & \multicolumn{3}{|c|}{ Macro elements (\%) } & \multicolumn{4}{|c|}{ Micro elements (ppm) } \\
\hline & & & & & & $\mathbf{N}$ & $\mathbf{P}$ & $\mathbf{K}$ & $\mathbf{F e}$ & $\mathbf{Z n}$ & $\mathrm{Mn}$ & $\mathbf{C u}$ \\
\hline & & 3 & & 1 & 7.33 & 1.8 & $\mathbf{0}$ & ? & 109 & 2.75 & 14.9 & 0.40 \\
\hline Compost tea & 6.87 & 2.21 & 23.8 & 13.8 & 11.04 & 1.44 & 0.45 & 0.78 & 211 & 74 & 82 & 54 \\
\hline
\end{tabular}

At the end of each experiment (2017/2018 and 2018/2019), the following parameters were determined:

\section{Vegetative growth:}

Increment height growth, stem diameter $(\mathrm{cm})$ and root length $(\mathrm{cm})$, as well as biomass fresh and dry weight $(\mathrm{gm})$ were measured.

\section{Chemical constituents:}

Total chlorophylls was determined in leaves according to the method described by A.O.A.C. (1980)and total carbohydrates percentage in dry stem was determined according to (Dubasitet al., 1956). The percentage of N,P and $\mathrm{K}$ were determined in dry leaves of plants and soil at the terminal of experiment since nitrogen was determined using micro Kjeldahl, while phosphorous was determined calorimetrically using ammonium molybdate and ammonium metavanadate according to the procedure outlined by Ryan $\boldsymbol{e t} \boldsymbol{a l}$., (1996).

\section{Layout of experiment:}

63 seedlings were selected for this study then divided to 7 treatments, each treatment included 9 seedling and 3 replicates every replicate was represented by 21 seedlings, which were arranged in a complete randomized block design.

All the obtained data during this study was subjected to analysis of variance method according to Snedecor and Cochran (1980). Meanwhile, differences between means were compared using Duncan`s Multiple range test at 0.05 level probability (Waller and Duncan, 1969).

Results And Discussion

\section{Increment height growth, stem diameter and root length}

Data in Table (2) reveal that the application of 50 $\%$ from NPK with potassium humate and compost tea gave the highest significant mean values of height growth, stem diameter and root length of Quercus robur where the mean values were 61.67, 1.208 and $43.67 \mathrm{~cm}$ in first season respectively, followed by those treated with NPK at rates of $75 \%$ plus potassium humate or compost tea which achieved in both seasons. On the other hand, the lowest ones were recorded by control treatment (without addition of any fertilizer)where the values were $40.33,0.844$ and $24.33 \mathrm{~cm}$ respectively, in first seasons. It can be concluded that treatments of $(50 \% \mathrm{NPK}+$ compost tea + potassium humat were significantly exceeded the height growth, stem diameter and root length of Quercus robur seedlings rather than those of control and other treatments in which the percentages of increase were $52.91,43.13$ and $79.49 \%$ over control respectively, on the other hand the results of second season were confirmed to those of first one where in the same line and appeared significantly differences among the treatments while the percentage of the increments were 54.69,34.60 and $79.69 \%$ respectively. These results may be due to the excessive and effortlessly higher chemical nutrients uptake, from mineral fertilizer alone or with potassium humate or compost tea addition adequate nutrients for vegetative growth of Quercus robur. 
The same results were obtained by Scharenbroch, (2013) who suggested that the shoot, root, total biomass, and the root/shoot (R/S) ratio of Quercus macrocarpa increased with highest compost tea concentration in the compact loam soil. Also, Agegnehu, et al., (2014) who concluded that the integrated soil fertility management plays a vigorous role in nutrient availability of short and longer-term, upkeep of organic matter in soil and crop productivity sustainability respectively. The integrated application of organic and inorganic fertilizers improved wheat productivity and the soil fertility status.

Table 2.Effect of NPK fertilizer, compost tea and potassium humate on increment height growth, stem diameter and root length (cm.) of Quercus robur seedlings in both seasons

\begin{tabular}{|c|c|c|c|c|c|c|}
\hline \multirow{2}{*}{ Treat. } & \multicolumn{2}{|c|}{ Increment height growth } & \multicolumn{2}{|c|}{ Stem diameter } & \multicolumn{2}{|c|}{ Root length } \\
\hline & 1 & 2 & 1 & 2 & 1 & 2 \\
\hline Control & 40.33F & 39.00G & $0.844 F$ & $0.896 \mathrm{C}$ & 24.33E & $24.67 E$ \\
\hline $100 \%$ NPK & 50.67D & 49.00D & 1.127B & 1.099B & 34.33C & 34.33C \\
\hline Compost tea(CT) & 44.67E & 43.00E & $0.923 E$ & $0.908 C$ & 29.33D & 30.00D \\
\hline potassium humate $(\mathrm{KH})$ & 43.67E & $40.67 \mathrm{~F}$ & 0.907E & $0.904 \mathrm{C}$ & 28.67D & 30.33D \\
\hline $75 \%$ NPK + (CT) & 56.67B & 55.67B & 1.071C & 1.126B & 39.33B & 40.67B \\
\hline $75 \%$ NPK + (KH) & 53.00C & 52.33C & 1.004D & 1.074B & 39.33B & 39.67B \\
\hline $50 \%$ NPK + (CT)+ (KH) & 61.67A & 60.33A & $1.208 \mathrm{~A}$ & $1.206 \mathrm{~A}$ & 43.67A & 44.33A \\
\hline
\end{tabular}

Means followed by the same capital letter (s) within the same column are not significantly different.

Also Sharif et al. (2002b) suggested that the application of potassium humate with $50 \%$ of NPK as a mineral fertilizers produced significant and economical wheat yield as well as maximum nutrient accumulation and it may be utilized as a hopeful source of organic fertilizer for improving crop productivity. Furthermore, in a pot experiment, Kumaret al. (2014) studied the effect of potassium humate applied at the rate of 0,5 and $10 \mathrm{mg} / \mathrm{kg}$ soil with 100 and $75 \%$ recommended rate of mineral fertilizers NPK $(60,30,30 \mathrm{mg} / \mathrm{kg})$ and $12.5 \mathrm{mg} / \mathrm{kg}$ zinc sulphate on growth and yield attributes of rice plant. They found that the addition of $10 \mathrm{mg} / \mathrm{kg}$ potassium humate along with $100 \%$ NPK fertilizers and $12.5 \mathrm{mg} / \mathrm{kg}$ zinc sulphate caused significant increase in plant height, number of tillers, panicle height, panicle length, test weight, straw yield and yield of rice as compared to 100 and $75 \%$ NPK alone. Biomass fresh and dry weight

Results in Table (3) show that the biomass fresh and dry weight of Quercus robur seedlings were improved significantly by adding $50 \%$ from NPK fertilizer alongside compost tea and potassium humate in both seasons, where maximize values were 123.08 and $122.16 \mathrm{~g} \mathrm{pot}^{-1} \& 52.70$ and $52.06 \mathrm{~g}$ pot $^{-1}$ for biomass fresh and dry weight in both seasons, respectively,in addition, the values of such parameters were increased significantly by sole application of $100 \%$ NPK fertilizer in both seasons. The relative increase were 25.94 and $25.24 \& 27.76$ and $26.16 \%$ for $50 \%$ from NPK fertilizer alongside compost tea and potassium humate over than those of $100 \%$ NPK fertilizer alone in both seasons, respectively. Alternatively, the lowest ones were obtained by control treatment (without addition of any fertilization) in both seasons. The effects of the K-humate substance on increasing growth and stimulant function in most physiological and metabolic process and metal activator of enzyme, resulted in increasing growth and development of Quercus robur seedlings. This improving may be due to the availability and speed solubility of mineral fertilizers which increase the rooting system of Quercus robur seedlings directly absorbed the nutrients in short time. In this connection, Angus Campbell (2007) found that the compost tea is commonly applied to the soil by drenching the soil, directing compost tea into the root zone and affects the rhizosphere of the plant. Macro and micronutrients supplied with the compost tea are used by the plants as well as by the microorganisms.

Table 3. Effect of NPK fertilizer, compost tea and potassium humate on biomass fresh and dry weight (gm.) of Quercus robur seedlings in both seasons

\begin{tabular}{|c|c|c|c|c|}
\hline \multirow{2}{*}{ Treat. } & \multicolumn{2}{|c|}{ Biomass F.W. (gm.) } & \multicolumn{2}{|c|}{ Biomass D.W.(gm.) } \\
\hline & 1 & 2 & 1 & 2 \\
\hline$\overline{\text { Control }}$ & 30.07F & 29.38F & $11.36 \mathrm{E}$ & 11.29F \\
\hline $100 \%$ NPK & 91.15B & 91.32B & 38.07B & 38.44B \\
\hline Compost tea(CT) & 86.30C & 86.23C & $36.45 \mathrm{C}$ & 25.08E \\
\hline potassium humate $(\mathrm{KH})$ & $74.46 \mathrm{E}$ & $75.43 E$ & 30.34D & 30.41D \\
\hline $75 \%$ NPK + (CT) & 86.46C & 86.73C & 38.55B & 38.01B \\
\hline $75 \%$ NPK + (KH) & 82.34D & 82.30D & $36.16 \mathrm{C}$ & 36.77C \\
\hline $50 \% \mathrm{NPK}+(\mathrm{CT})+(\mathrm{KH})$ & $123.08 \mathrm{~A}$ & 122.16A & 52.70A & 52.06A \\
\hline
\end{tabular}

Means followed by the same capital letter (s) within the same column are not significantly different. 
The increment in plant fresh and dry weight due to organic fertilizers plus NPK, is expected because the used fertilizers contained the main elements beside some growth regulators, which have amazing effect on photosynthesis and biosynthetic processes in plants, thus induced more and better growth. These results agreed with those of Laila, et al., (2014) who study the influence of mineral NPK (0 and $25 \%)$ and compost tea $\left(0,15\right.$ and $30 \mathrm{~cm}^{3} /$ seedling ) as soil applications every 15 days from March to October on growth and chemical constituents of "Aggizi" olive seedlings. In general, application of compost tea at 15 $\mathrm{cm} 3$ / seedling as soil drench with or without mineral NPK gave the best results for increasing all vegetative growth such as plant height increment \%, number of leaves/ seedling, dry weight of leaves $\%$, root length and number per seedling compared to control treatments without using mineral NPK or compost tea in growing season.Ferihat and Masa'deh, Yara, (2006) found that, young olive trees benefit from low NPK levels and N alone and additional fertilizers would not be significant. However, NPK are considering being essential nutrients for plant growth and development. The $16 \mathrm{~g}$ NPK and $32 \mathrm{~g} \mathrm{~N}$ significantly increased the shoot and root dry weight, this probably due to $\mathrm{N}$ concentration which increased dry matter accumulation in roots and decreased shoot: root ratio. Moreover, Osman et al. (2010) in olive leaves revealed that bio and NPK fertilizer treatments significantly increased number of shoots/ branch/ meter, number of leaves per shoot, shoot length, shoot diameter, leaf area, leaf fresh and dry weights.

Total chlorophyll (mg/gm.) and \% carbohydrates:

Data in Table (4) demonstrate that the application of $50 \%$ from NPK fertilizer alongside compost tea and potassium humate led to the highest significant value of total chlorophyll in both seasons. The same trend was recorded by adding $100 \%$ NPK fertilizer alone in the first season only and the differences were insignificant in between. While the lowest one was obtained by control treatment (without addition of any fertilization) in both seasons. Concerning total carbohydrates, the highest value was noticed using compost tea alone in the $1^{\text {st }}$ season, it may be attributed to compost tea contains vegetative portions of stems of common reed and white cattail which enriched with carbohydrate and organic amended. Conversely, the lowest one was recorded by adding $50 \%$ from NPK fertilizer alongside compost tea and potassium humate in both seasons. It may be due to this treatment ameliorated vegetative growth parameters using stored carbohydrate of stem in formation and differentiation recent portions consumed more carbohydrate in new cells led to a decreasing it in stem in harmony with obtained results of, Hendawy (2008) on Plantagoarenaria indicated that increased compost tea from 200 to 300 $\mathrm{ml} / \mathrm{l}$ significantly decreased total carbohydrates content.

Application of organic fertilizers without NPK could not adequate the nutrient supply that responsible for chlorophyll biosynthesis. However, supplementation of cow manure on the application of NPK significantly improved the nutrient absorption, so that chlorophyll biosynthesis was optimized. A high amount of chlorophyll is required to maintain photosynthetic pigments, and synthesize the enzymes that take part resulting in increased growth and yield of peanut plants, Ghosh et al., (2004),Amujoyegbe et al.,(2007) and Li et al.,(2017).

Table 4. Effect of NPK fertilizer, compost tea and potassium humate on total chlorophyll (mg/gm f.w.) and carbohydrates as \% of Quercus robur seedlings in both seasons.

\begin{tabular}{|c|c|c|c|c|}
\hline \multirow{2}{*}{ Treat. } & \multicolumn{2}{|c|}{ Total chlorophyll mg/gm f.w. } & \multicolumn{2}{|c|}{ Total carbohydrates \% } \\
\hline & 1 & 2 & 1 & 2 \\
\hline Control & $1.215 \mathrm{C}$ & 1.179D & $9.16 \mathrm{~B}$ & $10.05 \mathrm{~A}$ \\
\hline $100 \%$ NPK & $1.515 \mathrm{~A}$ & $1.378 \mathrm{~B}$ & $8.44 \mathrm{C}$ & 9.08B \\
\hline Compost tea(CT) & $1.269 \mathrm{C}$ & $1.265 \mathrm{C}$ & $10.06 \mathrm{~A}$ & 9.02B \\
\hline potassium humate (KH) & $1.266 \mathrm{C}$ & $1.262 \mathrm{C}$ & $9.82 \mathrm{AB}$ & $9.00 \mathrm{~B}$ \\
\hline $75 \%$ NPK + (CT) & $1.378 B$ & $1.376 \mathrm{~B}$ & $9.02 B C$ & $8.40 \mathrm{C}$ \\
\hline $75 \% \mathrm{NPK}+(\mathrm{KH})$ & 1.372B & $1.372 B$ & $9.08 B C$ & $9.04 B$ \\
\hline $50 \% \mathrm{NPK}+(\mathrm{CT})+(\mathrm{KH})$ & $1.479 \mathrm{~A}$ & $1.476 \mathrm{~A}$ & 8.49C & $8.42 \mathrm{C}$ \\
\hline
\end{tabular}

Means followed by the same capital letter (s) within the same column are not significantly different.

\section{Nitrogen, phosphorus and potassium percentage}

Table (5)illustrate that $100 \%$ from NPK fertilizer or the application of compost tea led to the highest significant values of N,P and $\mathrm{K}$ percentage of Quercus robur seedlings in both seasons. In most cases, the lowest ones were recorded by adding $50 \%$ from NPK fertilizer alongside compost tea and potassium humate in both seasons. Similar trend was noticed by applying potassium humate alone for $\mathrm{N}$ and $\mathrm{P} \%$ in the first season only. Potassium humate promote seedling height, increases nutrient uptake and stimulates plant growth. It promoted Quercus robur seedlings growth by its effects on ion transfer at the root level, by activating the oxidation reduction state of the plant growth medium and so improved absorption of macronutrients by preventing 
precipitation in the nutrient solution. These results could be explained according to the findings ofZaki, et al., (2013)who reported that applying of K-humate and rhizobia (Rhizobium leguminosarum), led to improving plant growth characters, i.e. plant height and dry weight of shoots. Moreover, the principal physiological function of potassium humate may be that they reduce oxygen deficiency in plants, which results in better uptake nutrients, also, enhances cell permeability, which in turn made for a more rapid entry of mineral into leaves cells and so resulted in higher uptake of plant nutrients. The same findings were observed by Mostafa et al. (2009) on orange. Mohammed et al. (2010) on pear and Allam et al. (2012) on grapevines. They found that applied compost tea to trees significant increase in leaf content of N,P and K compared with control.

Table 5. Effect of NPK fertilizer, compost tea and potassium humate on N,P and K percentage of Quercus robur seedlings in both seasons.

\begin{tabular}{|c|c|c|c|c|c|c|}
\hline \multirow{2}{*}{ Treat. } & \multicolumn{2}{|c|}{$\mathrm{N} \%$} & \multicolumn{2}{|c|}{$\mathbf{P \%}$} & \multicolumn{2}{|c|}{$\mathbf{K} \%$} \\
\hline & 1 & 2 & 1 & 2 & 1 & 2 \\
\hline Control & 0.540 & 0.600 & 0.715 & 0.700 & 0.400 & 0.403 \\
\hline $100 \%$ NPK & $1.044 \mathrm{~A}$ & $1.098 \mathrm{~A}$ & $0.0 .819 A$ & $0.822 A$ & $0.707 A$ & $0.708 A$ \\
\hline Compost tea $(\mathrm{CT})$ & $1.036 \mathrm{AB}$ & 1.071A & $0.0 .812 A$ & $0.811 A$ & $0.651 B$ & $0.669 B$ \\
\hline potassium humate (KH) & 0.771C-E & 0.833BC & 0.800A-C & $0.811 A B$ & $0.552 D$ & $0.552 E$ \\
\hline $75 \%$ NPK + (CT) & 0.824B-D & $0.765 C$ & $0.811 \mathrm{AB}$ & 0.790A-C & $0.573 D$ & $0.570 E$ \\
\hline $75 \%$ NPK + (KH) & $0.966 \mathrm{~A}-\mathrm{C}$ & $1.005 \mathrm{AB}$ & 0.817AB & 0.813AB & $0.618 C$ & $0.621 D$ \\
\hline $50 \% \mathrm{NPK}+(\mathrm{CT})+(\mathbf{K H})$ & $0.591 E$ & $0.610 \mathrm{C}$ & 0.810AB & $0.805 B C$ & $0.428 \mathrm{~F}$ & $0.428 \mathrm{~F}$ \\
\hline
\end{tabular}

Means followed by the same capital letter (s) within the same column are not significantly different.

Moreover, nutrient concentrations such as; $\mathrm{Ca}, \mathrm{Mg}, \mathrm{K}, \mathrm{P}$, and available $\mathrm{N}$ in the compost tea were elevated compared to those in the water treatment. However, only available soil $\mathrm{K}$ increased with compost tea compared with control. Background soil levels, nutrient fixation, uptake of tree, volatilization, and leaching losses may be responsible for the non-responses observed for other nutrients. These findings propose that compost tea may increase soil $\mathrm{K}$; however, $\mathrm{K}$ is rarely a limiting factor for plant growth. Hargreaves et al.(2008) found K levels to be lower with compost tea as compared with mineral fertilizer in agreement with herein results , but this was likely the result of the compost teas being applied as foliar sprays and fertilization as a soil application. Osman et al. (2010)revealed that bio and NPK fertilizer treatments significantly increased, N,P and $\mathrm{K}$ contents in olive leaves

In general, it could be concluded that application of $15 \mathrm{~g}$ NPK along with potassium humate $5 \mathrm{~cm}$ and compost tea at $15 \mathrm{~cm} / \mathrm{seedling}$ gave the best results for increasing all growth parameters and mineral content in Quercus robur seedlings grown under the same condition, thus it is not necessary to increase NPK as mineral nutrients in which $50 \%$ of NPK was sufficient and adequate.

Available nitrogen, phosphorus and potassium \% in soil after experiment:

Available data in Table (6)show that the adding of $50 \%$ from NPK fertilizer alongside compost tea and potassium humate or $75 \%$ from $\mathrm{NPK}+\mathrm{K}$-humate led to the highest significant values of available nitrogen, phosphorus and potassium of soil after experiment in both seasons. The same trend was found by applying potassium hamates alone for nitrogen and phosphorus in both seasons, respectively. Conversely, the lowest ones were obtained by control treatment or $100 \%$ from mineral fertilizers alone in both seasons. Such improving of abovementioned results may be due to the enhanced effect of the NPK nutrients released from organic fertilizers on photosynthesis assimilation rates, increasing the absorption of NPK by roots and accumulation of them in morphological parts.

Table 6. Effect of NPK fertilizer, compost tea and potassium humate on N,P and K \% of soil after experiments in both seasons

\begin{tabular}{|c|c|c|c|c|c|c|}
\hline \multirow{2}{*}{ Treat. } & \multicolumn{2}{|c|}{$\mathrm{N} \%$} & \multicolumn{2}{|c|}{$\mathbf{P \%}$} & \multicolumn{2}{|c|}{$\mathbf{K} \%$} \\
\hline & 1 & 2 & 1 & 2 & 1 & 2 \\
\hline Control & 39.78C & 38.45D & 11.2C & 11.46B & 333.25F & 339.14C \\
\hline $100 \%$ NPK & 38.03C & 38.53D & 11.5C & 11.44B & 345.65E & $360.22 B C$ \\
\hline Compost tea $(\mathrm{CT})$ & 40.50B & 39.75C & 12.8B & 11.98B & 364.25D & 370.14B \\
\hline potassium humate $(\mathrm{KH})$ & 41.58B & 42.14A & 14.01A & $13.85 A$ & 378.2C & 372.44B \\
\hline $75 \% \mathrm{NPK}+(\mathrm{CT})$ & 41.20B & 41.64B & 14.33A & 13.89A & 392.15AB & $390.45 \mathrm{~A}$ \\
\hline $75 \%$ NPK + (KH) & 42.19 A & 42.11A & $14.75 \mathrm{~A}$ & $14.25 \mathrm{~A}$ & 399.9A & 391.14A \\
\hline $50 \% \mathrm{NPK}+(\mathrm{CT})+(\mathrm{KH})$ & $42.84 \mathrm{~A}$ & 42.44A & 14.03A & 13.95A & 410.75A & $400.12 A$ \\
\hline
\end{tabular}

Means followed by the same capital letter (s) within the same column are not significantly different. 
Moreover, these results indicated that $\mathrm{K}$ humate had helpful effect on the different nutrients absorbed by plant. These results are in harmony with Scharenbroch, (2013)on Quercus macrocarpa, and Agegnehu, et al., (2014)on wheat.

However $50 \%$ of NPK with compost tea and K-humate gave the highest values for most of the studied characters compared with full dose of NPK only. Generally,50\%NPK+compost tea + K-humate considerably economical and save chemical NPK fertilizer to half the used dose, consequently decreasing the environmental pollution, high cost of chemical fertilization and produced the healthy seedlings of Quercus robur.

\section{pH,EC and OM of soil after experiments:}

Data in Table (7)reveal that the $\mathrm{pH}$ and EC of soil after experiments were slightly decreased by applying compost tea and potassium humate alone or together with soil application of $50 \%$ from NPK fertilizer compared to control treatment in both seasons. On the other hand, organic matter was enriched using the same treatments abovementioned compared to control treatment in both ones, it is clear that the treatment application of $50 \% \mathrm{NPK}+$ potassium hamate + compost tea resulted in restricted the values of both $\mathrm{PH}$ and EC more than the others treatments meaning that both of K-humate associated in maintenance the soil considering as soil conditioners substances. These findings are in agreement with El-Sharkawy (2007) on Guava, Ulkan (2008)on wheat,(Ali et al. 2009) on rice, and Osman et al., (2014)on wheat.

Table 7. Effect of NPK fertilizer, compost tea and potassium humate on $\mathrm{pH}$, EC and \% OM of soil after experiments in both seasons

\begin{tabular}{|c|c|c|c|c|c|c|}
\hline \multirow{2}{*}{ Treat. } & \multicolumn{2}{|c|}{ pH } & \multicolumn{2}{|c|}{ EC } & \multicolumn{2}{|c|}{ OM \% } \\
\hline & 1 & 2 & 1 & 2 & 1 & 2 \\
\hline Control & 7.75 & 7.74 & 1.28 & 1.29 & $\mathbf{1 . 0 8}$ & 1.06 \\
\hline $100 \%$ NPK & 7.79 & 7.78 & 1.27 & 1.26 & 1.09 & 1.08 \\
\hline Compost tea $(\mathrm{CT})$ & 7.74 & 7.75 & 1.15 & 1.16 & 1.11 & 1.10 \\
\hline potassium humate $(\mathbf{K H})$ & 7.68 & 7.70 & 1.16 & 1.16 & 1.14 & 1.15 \\
\hline $75 \%$ NPK + (CT) & 7.77 & 7.75 & 1.20 & 1.21 & 1.12 & 1.11 \\
\hline $75 \% \mathrm{NPK}+(\mathrm{KH})$ & 7.68 & 7.7 & 1.17 & 1.16 & 1.13 & 1.13 \\
\hline $50 \% \mathrm{NPK}+(\mathrm{CT})+(\mathrm{KH})$ & 7.68 & 7.65 & 1.16 & 1.15 & 1.15 & 1.11 \\
\hline
\end{tabular}

Means followed by the same capital letter (s) within the same column are not significantly different.

\section{References}

A.O.A.C. Association of Official Agricultural Chemists, (2000). "Official Methods of Analysis" Benjamin Franklin Station, Washington, D.C. USA. P. 495-510.

Agegnehu, G., C. Van Beek and M.I. Bird, (2014). Influence of integrated soil fertility management in wheat and tef productivity and soil chemical properties in the highland tropical. Environment journal of Soil Science and Plant Nutrition, 14: 532545.

Allam-Aida, M.A., F.F. Ahmed, N.N. El-Hefnawy, M.A. El-Hewety and H.A. El-Khafagy, (2012). Impact of inorganic $\mathrm{N}$ and compost enriched with some bacterial strains on fruiting of superior and flame seedless grapevines as well as activity of dehydrogenase enzyme in the soil. Minia J. of Agric. Res. and Develop.32(3): 495-510.

Ali, M.E, M.R. Islam and M. Jahiruddin, (2009). Effect of integrated use of organic manures with chemical fertilizers in the rice-rice cropping system and its impact on soil health. Bangladesh J. Agril. Res., 34: 81-90.

Al-Atrash, E.E.N, H.M. El-Zemrany, and A.H.M. Mohamed (2015). Effect of bio and mineral fertilization on growth of Khaya senegalensis and Cupressus sempervirens seedlings cultivated in sandy soil. J. Biol. Chem. Environ. Sci., 2015,Vol. 10 (3): $61-78$

Amujoyegbe, B.J., Opabode J.T and Olayinka A.(2007). African Journal of Biotechnology 6 1869-73.

Angus Campbell, (2007). Overview of Compost Tea Use in New South Wales Recycled Organics Unit. The University of New South Wales Sydney Australia $1466 \quad$ Internet: http://www.recycledorganics.com: Second Edition

Attia, F.A.; M.A. Abdou and M.A.H. Mohamed (2004). Physiological studies on ficusbenjamina L. Plants: Effect of Phosphorus fertilization and biofertilizers on seedling growth. J. Agric. Sci. Mansoura Univ., 29 (2): 775-785.

Diver, Steve, (2002). Notes on compost teas for plant disease control ATTRA publication available at httb://www.attra.org/attar-pub/comptea - htmt

Dubasit, M., K.A. Gilles, J.K. Hamilton, P.A. Reberand F. Smith(1956). Calorimetric method for determination of sugars and related substances. Anal. Chem. 28: 350-356.

El-Sharkawy, Sh. M.M. (2007). Response of guava trees to organic fertilization. The Third Conf. Of Sustain. Agric. Develop. Fac. Of Agric., Fayoum Univ., 12-14 Nov., 2007, 179-196.

Ferihat, N.M. and Yara K. Masa'deh (2006).Response of two-year-old tree of four 
olive cultivars to fertilization. Amrican- Erasian J. Agric. \& Environ. Sci., 1 (3): 185-190.

Ghosh, P.K., Ajay, Bandyopadhyay K.K., Manna M.C., Mandal K.G., Misra, A.K. and Hati, K.M.(2004).Bioresource Technology 95 85-93

Guthke, J. and Spethmann, W. (1993). Physiological and pathological aspects of longterm storage of acorns. Ann. Sci. For., 50 (Suppl.): 384-387.

Haggag-Laila, F., Merwad M.A., Shahin, M.F.M., Hoballah, E.M and Mahdy, H.A. (2014) Influence of Mineral NPK and Compost Tea as Soil Applications on Growth of "Aggizi" Olive Seedlings under Greenhouse Condition Middle East Journal of Agriculture Research, 3(4): 701706 ,

Hargreaves, J.C., M. Sina Adl, P.R. Warman and H.P. Vasantha Rupasinghe (2008). The effects of organic amendments on mineral element uptake and fruit quality of raspberries. Plant Soil 308:213-226.

Hendawy, S.F. (2008). Comparative study of organic and mineral fertilization on Plantagoarenaria plant. J. Applied Sciences Research, 4 (5): 500-506.

Huang, W., Z. Bai, D. Hoefel, Q. Hu, X. Lv, G. Zhuang, S. Xu, H. Qi and H. Zhang, (2012). Effects of cotton straw amendment on soil fertility and microbial communities. Front. Environ. Sci. Eng., 6:336-349.

Ingham, E., (2005). The compost tea brewing manual as printings. Soil Food Web Incorporated, vegan, 3: 31-32.

Johnson, P. S.; Shifley, S. R. and Rogers, R. (2002). The ecology and silviculture of oaks. CABI, New York, NY, p.503.

Klute, A. (1986). Methods of Soil Analysis. Part 1. 2nd ed. ASA and SSSA. Madison, Wisconsin, USA.

Kumar, D.A.P. Singh, P. Raha and C.M. Singh, (2014). Effects of potassium humate and chemical fertilizers on growth, yield and quality of rice (Oryza Sativa L.). Bangladesh J. Bot. 43: 183-189.

Kumar, V. and K.P. Singh, (2001). Enriching vermicompost by nitrogen fixing and phosphate solubilizing bacteria. Bioresource Technology, 76: 173-175.

Li, Y., Li, N., Luo P., Wang Y., Dai J and Yang, J.(2017). IOP Conf. Series: Materials Science and Engineering 274.

Manzanera, J.A. M.A. Bueno and J.A. Pardos (1996). Quercus rubur, L. (Pedunculate oak). In: Biotech. in Agric. and Forestry, 35. Trees IV (ed. By Y.P.S. Bajaj). Springer-Verlag. Berlin, Heideberg, pp., 321-341.

Mohammed, S.M., T.A. Fayed, A.F. Esmail and N.A. Abdou, (2010). Growth, nutrient statues and yield of Le-Conte pear trees as influenced by some organic and biofertilizer rates compared with chemical fertilizer. Bull. Fac. Agric. Cairo Univ., 61: 17-32.
Mostafa, M.F.M., M.S.S. El-Boray, A.F. Abd ElWahab and R.A. Barakat, (2009). Effect of enriched compost tea on Washington navel orange trees. J. Agric. Sci. Mansoura Univ., 34(10): 1-9.

Osman, S.M., (2010). Effect of mineral, Bio-NPK soil application of young olive trees and foliar fertilization on leaf and shoot chemical composition. Res.J Agric. and bio., Sci., 6(3): 311-318.

Osman, E.A.M.; Manal, A. Hassan and Dalia, A. Yassin, (2014). Mutual effect of organic and synthetic fertilizers on productivity and economic evaluation of bread wheat. j. of Soil Sci. and Agric. Engineering Mansoura Univ.

Page, A. L., R. H. Miller and D. R. Keeney (1982). Methods of Soil Analysis. Part 2. Soil Soc. Amer. Inc. Madison, Wisconsin, U.S.A.

Ryan, J., S. Garabet, K. Harmsen, and A. Rashid. (1996). A soil and plant Analysis Manual Adapted for the west Asia and North Africa Region. ICARDA, Aleppo, Syria. 140pp.

Saber, M., E. Hoballah, Fatma H. Abd-El-Zaher and Eman I. Al-Mowafy, (2011a). Decontamination of Enteric Pathogens in Swaged Soils by Certain Organic Amendments. Journal of Biotechnology Research, 11: 1- 15.

Saber, M., S. Badr-El-Din, N. Awad, and Z. Mohammed, (2011b).Composting certain agricultural residues to potting soils. Journal of Horticulture and Forestry Vol. 3(12), 351-357.

Saruhan, V., A. Kusvuran and S. Babat (2011). The effect of different HA fertilization on yield and yield components performances of common millet (Panicum miliaceum L.). Scient. Res. Ess., 6:663-669.

Sayed, R.M.M. (2001). Effect of some agricultural treatments on the growth and chemical composition of some woody tree seedlings. Ph.D. Thesis, Fac. Agric. Minia Univ.

Scharenbroch, B.C. (2013). Impacts of Aerated Compost Tea on Containerized Acer saccharum and Quercus macrocarpa Saplings and Soil Properties in Sand, Uncompacted Loam, and Compacted Loam Soils. HORTSCIENCE 48(5):625-632. 2013.

Scheuerell, S.J. and Mahaffee, W.F. (2002). Compost tea principals and prospects for plant disease control. Compost Sci. Util. 10:313-338.

Sharif, M., R. A. Khattak and M. S. Sarir, (2002b). Wheat yield and nutrients accumulation as affected by humic acid and chemical fertilizers. Sarhad J. Agric., 18: 323-329.

Shehata, M.S. and Darwiesh, Mona (1999). Seedlings growth and some chemical constituents of three Pinus species as affected by ammonium nitrate fertilizer. inufiya J. of Agric. Res. 24(2):589-609.

Snedecor, G.W. and W.G. Cochran, (1980). One way classification- Analysis of variance- The random effect model - Two ways classification (Eds) In Statistical Methods. The lo was state univ. Press Ames lowa USA, 215-273. 
Ulkan, H. (2008). Effect of soil applied humic acid at different sowing times on some yield components in wheat (Triticum spp.) Hybrids Inter. J. Bot., 164-175.

Waller, R.A. and C.B. Duncan, (1969). A bays rule for symmetric multiple comparison problem Amre. Stat Assoc. Jour. December: 1485-1503.
Zaki, R.N., M.S. Mahrous and Nawal, N. Michail, (2013). Effect of some simulative compounds on yield and chemical composition of faba bean plants grown under calcareous soil conditions. Egypt. J. of Appl. Sci., 28 (12B) .

$$
\begin{aligned}
& \text { استجابة النمو والتركيب الكيماوى لثتلات البلوط للتسميد العضوى والمعدنى }
\end{aligned}
$$

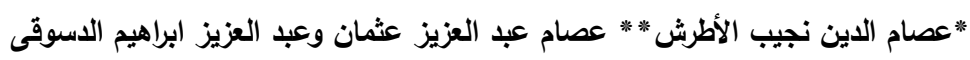

$$
\begin{aligned}
& \text { *قسم بحوث الأثجار الخشبية والغابات معهد بحوث البساتين **معهل بحوث الاراضى والمياه والبيئة- مركز البحوث الزراعية، الجيزة، مصر. }
\end{aligned}
$$$$
\text { اجرى هذا البحث بغرض دراسة استجابة النمو والتزكيب الكيماوى لثنتلات البلوط للتسميد العضوى (هيومات بوتاسيوم كسم/شتلد) او (كمبوست تى 15سم/ شتله }
$$

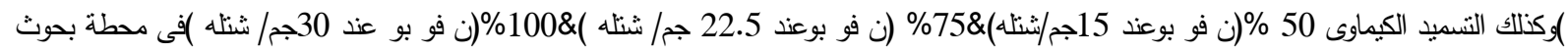

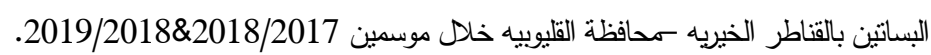$$
\text { وقد بينت النتائج ان الزياده المعنويه كانت فى النمو الطولى وقطر الساق وطول الجذر وكنلك الكتله الحيويه الطازجه والجافه عند اضافة 50\%من (ن فو بو }
$$

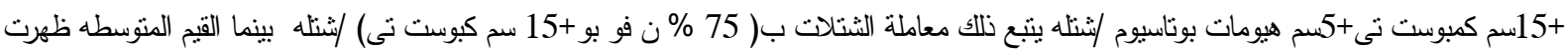

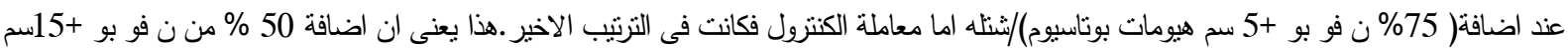

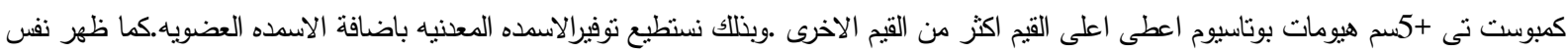$$
\text { الاتجاه تقريبا مع الكلوروفيلات فى حين ان الكربوهيدرات الكليه فى الساق كانت اعلى القيم عند اضافة كمبوست تى بـى بمفرده. اما بالنسبه لمستويات النتوجين }
$$

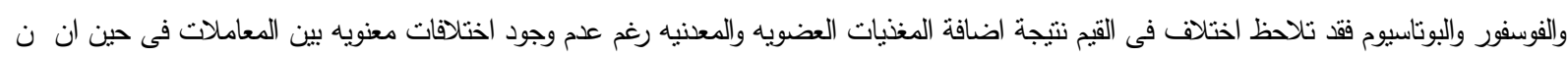

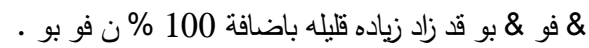

وبناء على ذلك يمكن التوصيه باضافة نصف جرعات التنميد المعنى (ن فو بو ) مع التسميد العضوى (كبوست تى +هيومات بوتانسيوم ) حيث ان ذللك يحسن

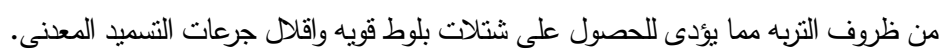

